\title{
The Management of Character Education Curriculum at Vocational High School 2 Kandangan
}

\author{
Suhaimi \\ Program Magister Manajemen Pendidikan \\ Fakultas Keguruan dan Ilmu Pendidikan \\ Universitas Lambung Mangkurat \\ Kandangan, Indonesia \\ suhaimi@ulm.ac.id
}

\author{
Yuli Rinawati \\ Sekolah Menengah Pertama Negeri 1 Paju Epat \\ Kecamatan Paju Epat \\ Barito Timur, Indonesia \\ yulirinawati@yahoo.com
}

\begin{abstract}
This research aims to know Management Education Curriculum with Character at SMKN 2 Kandangan. This study uses a qualitative descriptive approach. Data sources were obtained from the principal, head of the school committee, vice principal, homeroom teacher, teacher, and students. The technique of collecting data through interviews, observation, and documentation. Interactive data analysis, namely data reduction, data presentation, and conclusion drawing. Test data validity is done by triangulation of sources and methods. Based on the results of data analysis on, it was found that at the planning stage of character education curriculum by carrying out needs analysis, formulating and answering philosophical questions, determining curriculum design, making master plans. At the stage of organizing character education curriculum by making rational, structure/content, material organization, preparing teaching and learning activities, structure, tools, facilities/infrastructure, and determining the measurement of learning outcomes. At the implementation stage of the character education curriculum by making plans and learning programs, elaborating the material, determining strategies and methods, providing resources, tools, and facilities, determining the methods and tools for evaluating learning processes and outcomes, and setting the learning environment. At the stage of character education curriculum assessment through teacher education curriculum assessment and assessment of the obstacles/problems faced by the school. It was concluded that the management of character education curriculum in SMK 2 Kandangan had implemented steps in education management, which consists of aspects of planning, organization, implementation, and evaluation.
\end{abstract}

Keywords: Education Character, Curriculum Education with Character.

\section{INTRODUCTION}

Quality learning is not only determined by curriculum renewal, available facilities, sympathetic teacher personality, meaningful learning, broad knowledge of teacher knowledge about all fields of study but also teacher mastery of classroom management [1].

Based on a preliminary study at SMK 2 Kandangan, it turns out that the school has implemented Regional Regulation No.3 of 2009 since the last two years, through the curriculum of local content with Ethics Education (Character) subjects. Of the 18 Vocational School Vocational Schools in Kandangan selected 2 Kandangan Vocational Schools, is a representative of educational institutions that have implemented character education for their students.

The facts are as follows: 1) SMK 2 Kandangan has programmed ethical/character material in the curriculum. 2) The principal as the top manager of the education sector in the school wants to make students really have character, 3) Field curriculum: want more comprehensive character curriculum implementation, 4) Teachers: as many as 29 lecturers in accordance with the field of study taught have made RPP (Learning Implementation Plan) characters from both MGMP and the internet, 4) Infrastructure supporting facilities such as prayer room, laboratory, library, canteen, field, multi-media room. 5) Students: have motivation and interest in learning, but for students' interest in reading is still low, it is found that students often violate school rules such as painted hair, use HP while studying, littering, not well dressed, slowly marching when starting flag ceremony.

The solution to the problems above, SMK 2 Kandangan implement Character Curriculum that prioritizes building character in students who are oriented to the formation of the character of students. This is based on facts and public perceptions about the declining quality of attitudes and morals of children or the younger generation.

Based on the explanation above, the researcher was interested in conducting research with the title: Character Education Curriculum Management at SMK 2 Kandanganl. This study aims to explore describing: 1) Character Education Curriculum Planning in SMK 2 Kandanganl, 2) Organizing Character Education Curriculum in SMK 2 Kandanganls, 3) Implementation of Character Education Curriculum in 2 Kandangan Vocational Schools, and 4) Character Education Curriculum Assessment in Vocational High School 2 Kandangan.

\section{LITERATURE REVIEW}

Management, according to reference [2], is a science and art governing the process of utilizing human resources and other sources effectively and efficiently to achieve certain goals. Management comes from the word to manage which means managing. 
According to reference [3], education management functions can be visualized through the following picture:

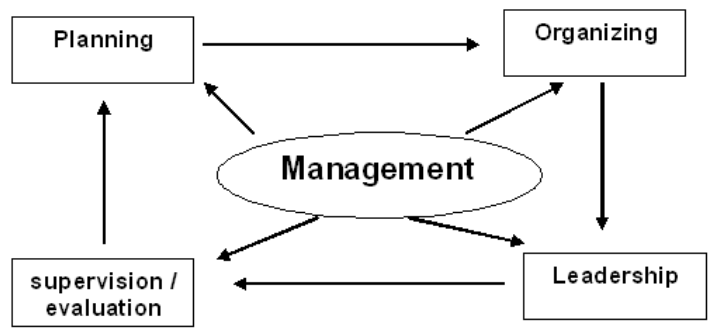

Fig. 1. Cycle Manajemen

School management, gives full authority to the school to plan, organize and direct, the components of school education, including 1) student input (student), 2) curriculum, 3) education staff, 4) facilities, 5) funds, 6) environment (school relationship with the community), and 7) teaching and learning activities, which are diagrammatical as below.

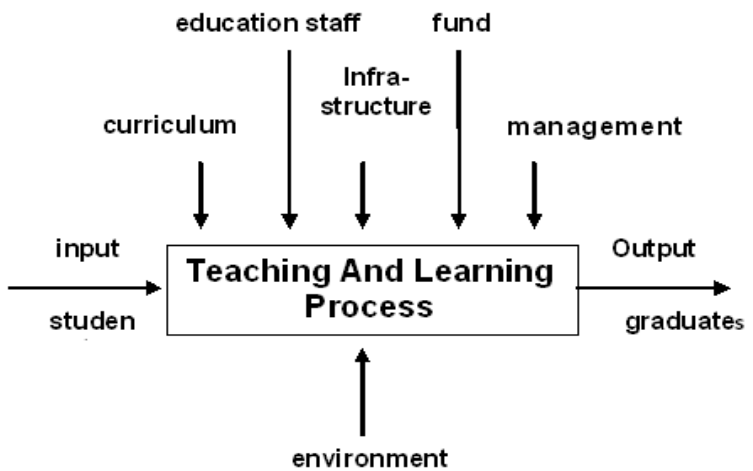

Fig. 2. Various components of education that need to be managed in implementing education

\section{A. Character Curriculum and Development}

The character curriculum content and development is believed to be necessary and important to be carried out by the school to become a foothold in the implementation of character education in schools. the best and do everything right and have life goals [4]

\section{TABLE I. Character VAlues to DeVEloP In StUdents}

\begin{tabular}{|l|l|}
\hline 1. Religious & $\begin{array}{l}\text { Attitudes and behavior are obedient in carrying out the } \\
\text { teachings of the religion they adhere to. }\end{array}$ \\
\hline 2. Honest & $\begin{array}{l}\text { Behavior that is based on efforts to make himself a } \\
\text { person who can always be trusted in words, actions, and } \\
\text { work. }\end{array}$ \\
\hline 3.Tolerant & $\begin{array}{l}\text { Attitudes and actions that respect differences in } \\
\text { religion, ethnicity, ethnicity, opinions, attitudes, and } \\
\text { actions of others are different from that. }\end{array}$ \\
\hline
\end{tabular}

\begin{tabular}{|l|l|}
\hline 4. Discipline & $\begin{array}{l}\text { Actions that show orderly behavior and adhere to } \\
\text { various provisions and regulations }\end{array}$ \\
\hline 5. Hard work & $\begin{array}{l}\text { Behavior that shows genuine effort in overcoming } \\
\text { various learning and assignment tasks }\end{array}$ \\
\hline 6. Creative & $\begin{array}{l}\text { Think and do something to produce new ways or results } \\
\text { from what you already have. }\end{array}$ \\
\hline 7. Independent & $\begin{array}{l}\text { Attitudes and behaviors that are not easily dependent on } \\
\text { others in completing tasks }\end{array}$ \\
\hline 8. Democratic & $\begin{array}{l}\text { how to think, behave and act that assesses the rights and } \\
\text { obligations of himself and others }\end{array}$ \\
\hline 9. Curious & $\begin{array}{l}\text { attitudes and actions that always strive to know more } \\
\text { deeply }\end{array}$ \\
\hline 10. Nationalistic & $\begin{array}{l}\text { ways of thinking, acting, and insight that place the } \\
\text { interests of the nation and state above the interests of } \\
\text { themselves and their groups. }\end{array}$ \\
\hline $\begin{array}{l}\text { 11. Loving the } \\
\text { country }\end{array}$ & $\begin{array}{l}\text { The way to think, behave and act that shows loyalty, } \\
\text { caring, and a high appreciation for the language, } \\
\text { physical, social, cultural, and national environment. }\end{array}$ \\
\hline $\begin{array}{l}\text { 12. Valuing } \\
\text { Achievement }\end{array}$ & $\begin{array}{l}\text { Attitudes and actions that encourage themselves to } \\
\text { produce something useful for society, }\end{array}$ \\
\hline $\begin{array}{l}\text { 13. Friendly/ } \\
\text { communicative }\end{array}$ & $\begin{array}{l}\text { Actions that show pleasure in talking, associating, and } \\
\text { collaborating with others. }\end{array}$ \\
\hline 14. Peaceful & $\begin{array}{l}\text { Attitudes, words, and actions that cause other people to } \\
\text { feel happy and safe for their presence }\end{array}$ \\
\hline $\begin{array}{l}\text { 15. Loving to } \\
\text { read }\end{array}$ & $\begin{array}{l}\text { The habit of providing time to read various passages } \\
\text { that provide virtue for him. }\end{array}$ \\
\hline $\begin{array}{l}\text { 16.environment- } \\
\text { care }\end{array}$ & $\begin{array}{l}\text { Attitudes and actions that always strive to prevent } \\
\text { damage to the surrounding natural environment, }\end{array}$ \\
\hline 17. Social-care & $\begin{array}{l}\text { Attitudes and actions that always want to help others } \\
\text { and the people in need }\end{array}$ \\
\hline 18. Responsible & $\begin{array}{l}\text { The attitude and behavior of a person in carrying out } \\
\text { their duties and obligations to themselves, society, } \\
\text { environment }\end{array}$ \\
\hline
\end{tabular}

\section{B. Conceptual Framework}

The character education curriculum is intended by principals and teachers, so students are equipped with, science, technology, and morals. This conceptual framework is used to clarify where the direction of this research is carried out, illustrated as follows figure 3 .

The curriculum is an educational design that summarizes all learning experiences provided for students at the school. In the integrated curriculum of philosophy, values, knowledge, and actions of education. Currently, the character education curriculum is a new curriculum that must be implemented in schools including in Vocational Schools

Deputy headmaster of the curriculum field plays a role as coordinator of the implementation of the curriculum. Study field teachers must explore the implementation of the character education curriculum starting from syllabus making, lesson plans, implementation of teaching to assessment. The principal as an education manager needs to implement character education curriculum management the school he leads. Therefore, the principal makes a program and implements education management in the field of character education curriculum both planning, organizing, implementing and evaluating. 


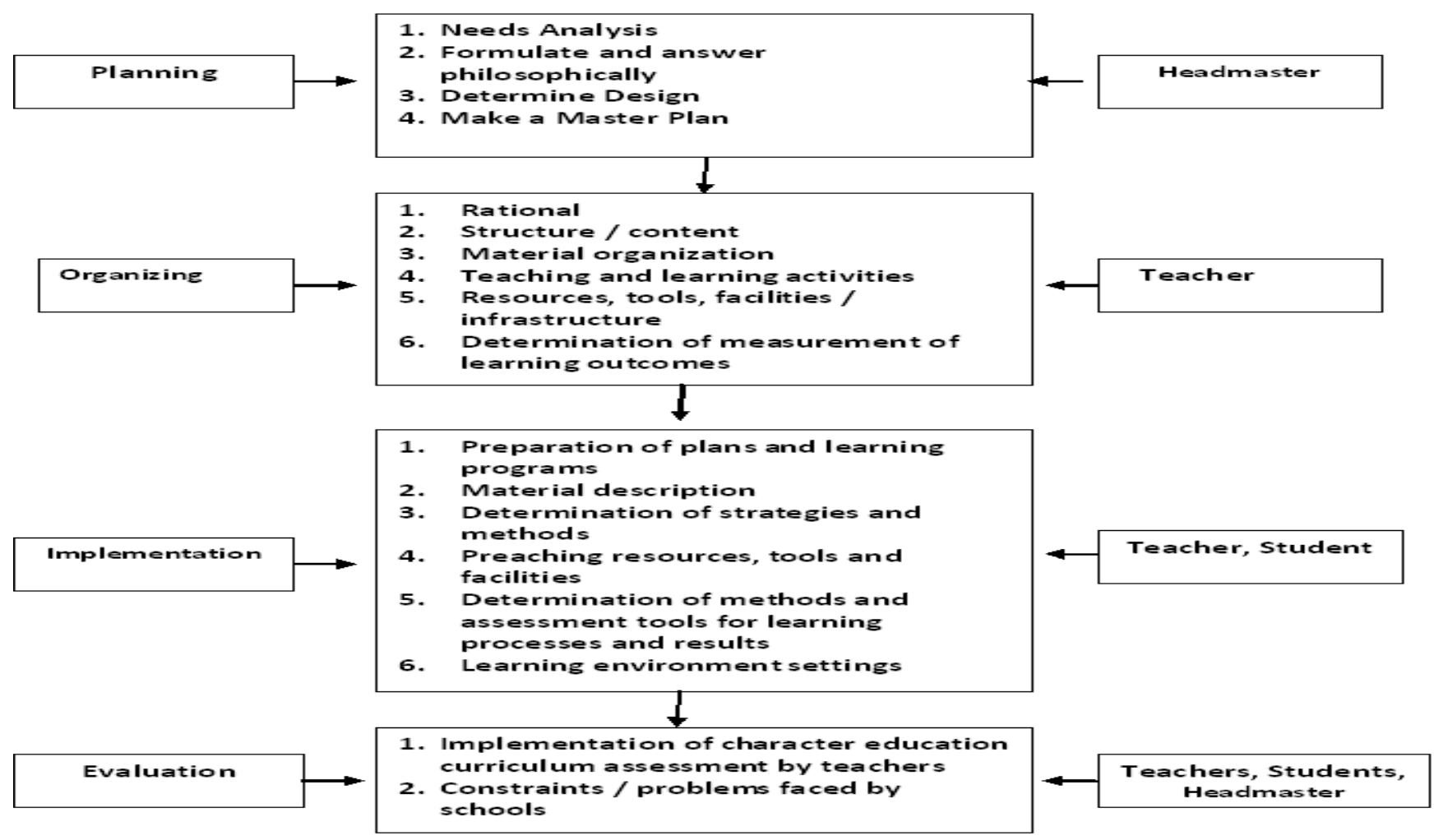

Fig. 3. Conceptual Framework

Based on the concept or design made, the research to be carried out at VOCATIONAL SCHOOL 2 Kandangan is as follows: a) character education curriculum planning, b) organization of character education curriculum, and c) implementation of character education curriculum Character education curriculum assessment.

\section{METHODS}

The approach used in this research is a qualitative approach because in describing data in the form of written or oral words from people and observable behaviors it would be more appropriate to use a qualitative approach. Furthermore, this study aims to describe the implementation of character education curriculum management at SMK 2 Kandangan.

SMK 2 Kandanganl as a place of research, because from a visit to a preliminary study of 18 equivalent Vocational Schools in Kandangan, it was found the fact that SMK 2 Kandangan had programmed ethical / character material in the curriculum. SMK 2 Kandanganl which was the location of the research address at Jalan Simpang Gambah In Walanko Kandangan RT. 15, Gambah Dalam Village, Kandangan District, Kandangan City.

Data sources were obtained from the principal, vice principal, subject teacher, homeroom teacher, and students from the informants who have set the criteria through purposive sampling. There are three types of data collection procedures in qualitative research, namely: (1) interviews; (2) observation; and (3) documentation.

Data analysis involves working on organizational data, evaluating into certain units, synthesizing data, tracking patterns, discovering important and learned things, and determining what to say to others. Data analysis is done through three lines of activities that occur simultaneously, namely: (1) data reduction, (2) data display, and (3) conclusion drawing/verification.

The validity of the data is a demand that must be fulfilled in each study included in qualitative research. The validity of the data used here uses Triangulation. Triangulation is the most commonly used method for increasing validity in qualitative research. Source triangulation is used, as well as the triangulation of methods to determine the validity of the data obtained. The criteria that must be fulfilled in determining the validity of the data are as follows: (1) credibility; (2) transferability; (3) dependability; and (4) commitment or certainty (objectivity). 


\section{RESULT AND DisCUSSION}

Based on data from interviews, observation, and documentation, then in this study found the following:

\section{A. Characteristic Education Curriculum Planning at SMK 2 Kandanganl}

\section{1) Planning Needs Analysis}

Head of SMK 2 Kandangan together with the teacher board and school committee have conducted a character education curriculum planning needs analysis at SMK 2 Kandangan through an analysis of the opportunities and challenges facing the school today, including having as many as 419 students consisting of 188 students and 213 women. But in terms of challenges, because they are abundant from public schools. The condition of students aged 15-18 years also presents a challenge, their behavior is unstable, seeing the current conditions and situations of teenage children are vulnerable to moral and ethical violations. Most Kandangan Vocational High School students live in suburban neighborhoods, 50\% more difficult to regulate, their behavior is still wild. the level of indiscipline of students from PGRI 6 Kandangan tends to be greater.

\section{2) Formulating and Responding to Philosophical Questions}

Regarding and formulating and answering philosophical questions, character education curriculum planning for SMK 2 Kandangan summarizes or integrates the character parts into a comprehensive and meaningful thing, by trying to see things objectively and eliminate subjective matters. Philosophically, discussing all the problems faced by humans, including the problem of character education which is quite degenerate, nowadays. Aims to solve educational problems, which are currently being discussed in society. School is philosophical, a place to form the good character for students through habituation and carried out through continuous, organized, reconstructed educational processes and changing life experiences.

\section{3) Determining Character Education Curriculum Design}

Regarding the character education curriculum design in SMK 2, Kandangan is a curriculum integrated with character education, with the name ethics education starting in class $\mathrm{X}$, $\mathrm{XI}$ and XII. The plan is a tiered implementation since entering school until graduating.

Then the other design is from subject teachers designing character education curriculum by linking the subject matter taught from school/character design ethics. The teacher prepares the lesson plan, then describes it according to their respective fields. Each field of study is different. Character education curriculum that is to be achieved in each subject matter studied will have an impact on the future of students, to manners, morals, such as respecting both the thoughts or opinions of others and in a very tolerant attitude means that every human being has differences in the physical and in mind.

\footnotetext{
4) Creating a Master Plan for Character Education Curriculum
}

In connection with making a master plan for character education curricula, the 2 Kandangan Vocational School is called Character Education Level Curriculum Development (curriculum). The master plan made by the character/ethics education curriculum with a short-term plan (1 year) involves: 1) attendance with a target of $95 \%, 2$ ) students have good morality such as working hard, having knowledge, high discipline, good environmental insight and have adequate skills that can carry it out in daily life in a personal and school environment, 3) $50 \%$ of students who are Muslim can read the Qur'an properly and correctly.

Medium-term planning (4 years) includes: 1) attendance of $97 \%$ students, 2) NUAN achievement target average of 6,00 graduates, 3) students $80 \%$ of students who are Muslim can read the Qur'an well and right, 4) students have ethics and culture in their personal, social, school, community.

Long-term programs (9 years), namely: 1) $98 \%$ student attendance, 2) NUAN achievement target average of 7,00 graduates, 3) 80\% of students can read the Qur'an / holy book properly and correctly, and students have moral character, and 4) students have ethics and culture in personal, social relationships in the community.

\section{B. Organizing Character Education Curriculum at SMK 2 Kandangan}

\section{1) Rational Organizing}

Based on the results of interviews, observation, and documentation, the rational management of the school curriculum with the character of the school makes the management aspect of the headmaster in charge, the supervisors are the school committee, the coordinator of the vice principal in the curriculum and as executors are teachers, homeroom staff and assisted administration staff.

\section{2) Organization of Structure / Content}

Organizing the structure/content of character education curriculum is carried out by SMK 2 Kandangan through integrating character/ethics education into the contents of each subject matter content. The structure/content of the character education curriculum from that is a curriculum that is elaborated and integrated with the content of character/ethics in accordance with the subject matter, in accordance with the basic competencies.

\section{3) Organization of Character Education Curriculum} Materials

In the organization of character education, curriculum materials are arranged by each teacher through the instructions of the vice principal of the curriculum field. The teachers prepare the character education curriculum material in the lesson plan. In the RPP character education is described: greetings, students stand up to respect the teacher/father, prayers are led by the class leader, then the teacher presents subject matter that is related to ethics, the teacher closes the lesson, prays and gives greetings.

\section{4) Organization of Teaching and Learning}

The school creates an organization of teaching and learning activities and self-development through a schedule of 
teaching assignments from Monday to Saturday from 7.30 to 14.00 .

\section{5) Sources, Tools, Facilities / Infrastructure}

Organizing resources, tools, facilities/infrastructure for character education curriculum has been made by the school, especially the use of resources, tools, facilities, and infrastructures such as prayer rooms, ceremonies, student work practices, and others. The teacher carries out resources and tools such as books, facilities/infrastructure such as the musholla and others whose use is in accordance with the field taught by the teacher.

\section{6) Determination of Learning Outcomes}

Determination of measurements of character education curriculum learning outcomes is determined by the school, which must be adhered to by every teacher and student. Measurement of learning outcomes is in affective and personality with very good (A), good (B), sufficient (C) and not good (D). At a minimum student get grades $A$ and $B$, if students get a $\mathrm{C}$, they will be considered to go up to class, if they get a D value then they don't go up. Determination of measurement of learning outcomes has been delivered by the school to students and parents of students.

\section{Implementation of Character Education Curriculum at SMK 2 Kandangan}

\section{1) Preparation of Learning Plans and Programs}

All teachers at Kandangan 2 VOCATIONAL SCHOOL must prepare learning plans and programs especially those that have already received certification. Preparation of plans and learning programs is the elaboration of character education curricula according to each teacher's field of study.

Submitting the obligation to formulate plans and learning programs is carried out verbally by the principal through the deputy head of the curriculum in the curriculum and directly to the teacher. In general, the teachers have implemented it, but some are late in making it.

The teachers draw up plans and learning programs by describing CURRICULUM into character education curriculum in each basic competency included elements of character such as virtuous character, noble character, mutual cooperation, cooperation, mutual respect, hard work.

\section{2) Elaboration of Material}

The description of character education curriculum material carried out by teachers in lesson plans according to their respective fields of study in teaching and learning activities, then applied in daily activities such as shaking hands when fellow school members meet, greet each other, perform congregational prayers during religious studies at hours last, etc. outside of study hours to support the implementation of the character education curriculum at SMK 2 Kandanganl .

\section{3) Determination of Strategies and Methods}

The strategies implemented in the character education curriculum at SMK 2 Kandangan are from the principal to delegate to the vice principal, also to the teachers. The teachers then convey to the students. The method used is generally lectures, question and answer, assignments, activities/actions, examples of example. The implementation is in the form of good values such as religious, honest, tolerant, disciplined, hard work, creative, independent, democratic, curiosity, national spirit, love for the country, respect for achievement, friendship (communication), peace of mind, love to read, caring for social, environmental care, and responsibility.

\section{4) Provision of Resources, Tools, and Facilities}

The provision of resources, tools, and facilities in the character education curriculum at SMK 2 Kandangan is all teachers who must behave politely and politely, reading material in library books, praying at the prayer room, laboratory practice activities, ceremonial discipline in the ceremonial grounds, honesty canteens, classrooms, science practice rooms, skills, equipment used for example the Qur'an for Muslims with joint recitation, examples, images as well as IT media. Facilities that are widely used are classrooms and in the school environment.

5) Determination of Methods and Tools for Process Assessment and Learning Outcomes

Determination of methods and assessment tools for learning processes and results carried out in the character education curriculum at Kandangan 2 Vocational School as stated by the Head of SMK 2 Kandangan through the application of daily discipline and teaching and learning process. The assessment tool is through credit points and teacher assessment results. A logbook of violations of student points in the daily supervisor and the assessment results of the teacher teaching in the class is provided.

\section{6) Setting the Learning Environment}

The setting of the learning environment looks normal, not changed and goes according to learning activities. Even for activities such as reading the Qur'an, praying and teaching and learning activities are also carried out in the classroom. Except for congregational prayer activities, cleaning activities, flag ceremonies, practices are carried out in their respective places that have been provided. If for shaking activities, students must shake hands with the teacher in front of the class or wherever the students meet.

\section{Character Education Curriculum Assessment at SMK 2 Kandangan}

1) Implementation of Character Education Curriculum Assessment by Teachers

The implementation of character education curriculum assessment by teachers through guidelines made by schools, namely for the implementation of character or ethics education, at least students get a B score. Assessment has not been implemented specifically but included in affective and personality. The assessment is taken from the results of discipline or violations committed by students through the notes given by the teacher, or from the records of students who commit violations, if the student $25 \%$ gets the violation weight the parents will be called 1, the violation value is $50 \%$ and the parents the value of $75 \%$ of parent violations of students is called and their children are expelled from school. The inability of students is only around 2-3 people. So the implementation of credit points already has the number and types of violations. 
There are plus points such as the above 100 can be rewarded and bring a good name to the school, will get a prize from the school. Likewise, if the violation, the student gets a minus point which if collected to certain limits will be handled seriously by BP, the homeroom teacher, and the principal. Character education curriculum assessment is included in affective and personal values with categories $\mathrm{A}, \mathrm{B}, \mathrm{C}$ and $\mathrm{D}$. For the values of $\mathrm{C}$ and $\mathrm{D}$; it is considered to go up to class.

Implementing teachers and homerooms, through several stages related to: (1) Obedience in implementing student discipline every day, through credit points, (2) assessment in class by subject matter teachers then reported to homeroom teacher, by guardian class character assessment included in student report cards both in semester I and semester II. (3) in school documents if students violate students are subject to sanctions, and if students obey the school rules and get achievements, they will be rewarded from the school.

Appraisers in the implementation of the character education curriculum are (1) study teachers, (2) homeroom teachers, (3) teachers in daily supervisors, (4) Counseling Guidance (BK) teachers, (5) principals.

\section{2) Problems / Problems Faced by Schools}

The obstacle in assessing character education curricula by teachers is that schools, in particular, have not provided guidance on ways of evaluating the implementation of this character education curriculum. The assessments carried out by the teachers are based on observations and records of violations and conform to the assessment of affective and personality aspects, which are in accordance with the school provisions.

\section{CONCLUSION}

Character education curriculum management at SMK 2 Kandangan has implemented steps in education management, namely 1) character education curriculum planning by conducting needs analysis, formulating and answering philosophical questions, determining curriculum design, making master plans, 2) organizing character education curricula by making rational, structure / content, organization of materials, preparation of teaching and learning, structure, tools / infrastructure, and determination of learning outcomes measurement, 3) implementation of character education curriculum by making plans and learning programs, elaborating material, determining strategies and methods, providing resources, tools and facilities, determination of methods and assessment tools for learning processes and results, and learning environment settings; and 4) assessment of character education curriculum through teacher education curriculum evaluation and assessment of problems/problems faced by schools.

\section{REFERENCES}

[1] R. Rahman, Kurikulum Tingkat Satuan Pendidikan, Bandung: Remaja Rosdakarya, 2008.

[2] M. S. P. Hasibuan, Manajemen sumber daya manusia: dasar dan kunci keberhasilan. Jakarta: Penerbit Gunung Agung, 2005.

[3] D. Sudirman, Dasar-Dasar Manajemen, Bandung: Armico, 2009.

[4] K. Kemendiknas, Kurikulum berbaris kompetensi, konsep, karakteristik dan implementasi, Dirjen Depdiknas RI, 2011 